\title{
Observations on non-random distribution of spores of Henneguya spp. (Cnidaria: Myxosporea: Myxobolidae) within plasmodia
}

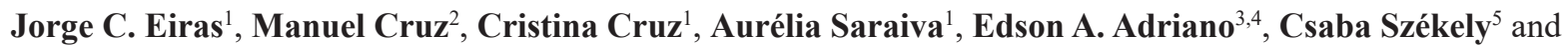 \\ Kálmán Molnár ${ }^{5}$

\begin{abstract}
${ }^{1}$ Departamento de Biologia, Faculdade de Ciências, Universidade do Porto, Portugal; Centro Interdisciplinar de Investigação Marinha e Ambiental (CIIMAR/CIMAR), Matosinhos, Portugal;

${ }^{2}$ Laboratório de Engenharia Matemática (LEMA), Instituto Superior de Engenharia do Porto, Portugal;

${ }^{3}$ Departamento de Ecologia e Biologia Evolutiva, Universidade Federal de São Paulo (UNIFESP), Diadema, São Paulo, Brasil;

${ }^{4}$ Departamento de Biologia Animal, Instituto de Biologia, Universidade Estadual de Campinas, Brasil;

${ }^{5}$ Institute for Veterinary Medical Research, Centre for Agricultural Research, Hungary; Hungarian Academy of Sciences (MTA), Budapest, Hungary
\end{abstract}

\begin{abstract}
Species of the cnidarian genus Henneguya Thélohan, 1892 (Myxosporea: Myxobolidae) are histozoic parasites commonly found in freshwater and, more rarely, in marine fish. The development of these parasites in fish tissues includes the formation of plasmodia within which occurs the sporogony originating spores with two caudal processes, which are usually randomly distributed within the plasmodia. In this report the authors present some cases of non-random distribution of the spores of six species of Henneguya within their plasmodia. Two different patterns of non-random distribution were found based on a literature survey. These patterns and their origin are discussed. Apparently this non-random distribution of the spores is due to both internal and external factors.
\end{abstract}

Keywords: Myxozoa, fish, parasites, spores arrangement, motility

The Myxosporea are endoparasites characterised, in general, by a two-host life cycle, which typically involves invertebrates and vertebrates as definitive and intermediate hosts, respectively (Okamura et al. 2015). The formation of spores by myxosporeans is of paramount importance to these organisms since the spores are infective stages which allow the infection of the next host contributing decisively for the completion of the parasite life cycle.

Spores are formed inside plasmodia as a result of a complex developmental cycle whose details are not yet completely understood, involving different kinds of cells, resulting in the formation of a variable amount of mature spores that usually fill completely the plasmodia. The size of plasmodia is variable, from minute structures to more or less rounded, elongated or branched-like ones, which may reach more than one centimetre in length. There are countless published photographs of histological sections of plasmodia concerning species of most of the myxosporean genera where those characteristics may be observed.

In almost all of the photographs the spores are apparently randomly distributed within plasmodia without any kind of spatial organisation. However, under rare occasions, some species of Henneguya Thélohan, 1892 show clearly a non-random distribution, presenting a well defined structured spatial distribution which suggests strongly it was not obtained by chance. A literature survey provided the observation of some cases of such a distribution which are discussed in this paper.

Henneguya creplini (Gurley, 1894) infecting the gills of Perca fluviatilis Linnaeus (Perciformes: Percidae) in Europe forms round plasmodia in the gills. The spores are clearly disposed in spiral-shaped form, sometimes with the body slightly twisted, apparently fitting more efficiently into the available space (Fig. 1A). The picture suggests that the orientation of the spores optimises their distribution within the plasmodium maximising the filling of the available space.

Henneguya visibilis Moreira, Adriano, Silva, Ceccarelli et Maia, 2014, parasitising the connective tissue of the fins of Leporinus obtusidens (Valenciennes) (Characiformes: Anostomidae) in Brazil, has non-random arrangement of the spores inside plasmodia, although the regularity of 

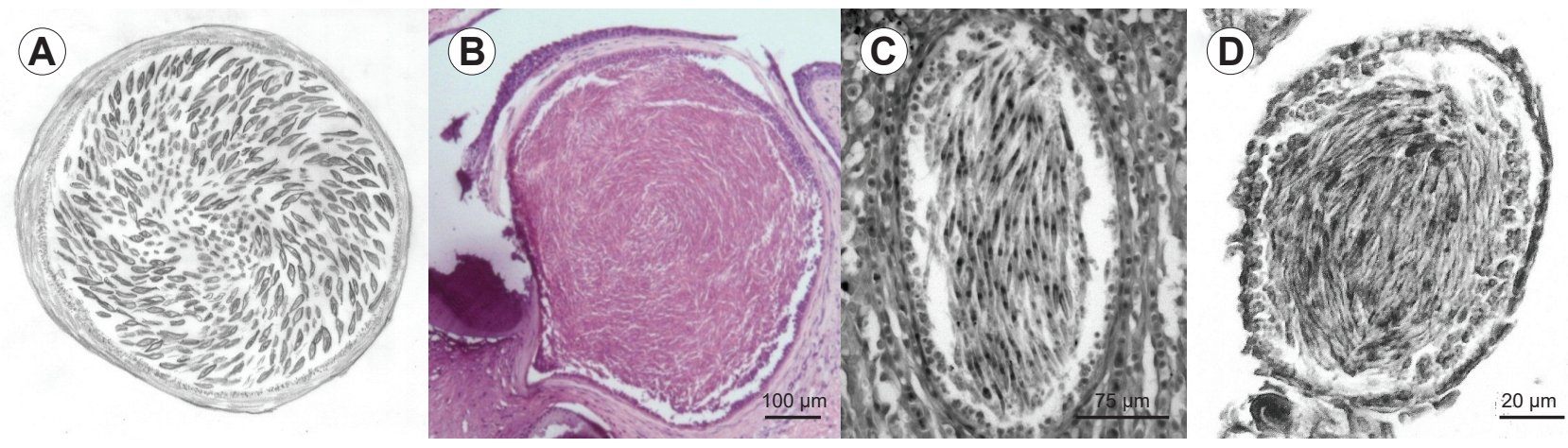

Fig. 1. A - Henneguya creplini (Gurley, 1894) in the gills of Perca fluviatilis Linnaeus - redrawn from a micrograph of Dyková and Lom (2007); B - Henneguya visibilis Moreira, Adriano, Silva, Ceccarelli et Maia, 2014 in the connective tissue of the fins of Leporinus obtusidens (Valenciennes) - photo by E. Adriano in Moreira et al. (2014); C - Henneguya piaractus Martins et Souza, 1997 in the gills of Piaractus mesopotamicus (Holmberg) - photo by J.C. Eiras in Eiras et al. (1999); D - Henneguya corruscans Eiras, Takemoto et Pavanelli, 2009 in the gills of Pseudoplatystoma corruscans Spix et Agassiz - photo by J.C. Eiras reproduced with permissison of Elsevier (Veterinary Parasitology, doi: 10.1016/j.vetpar.2008.10.020).

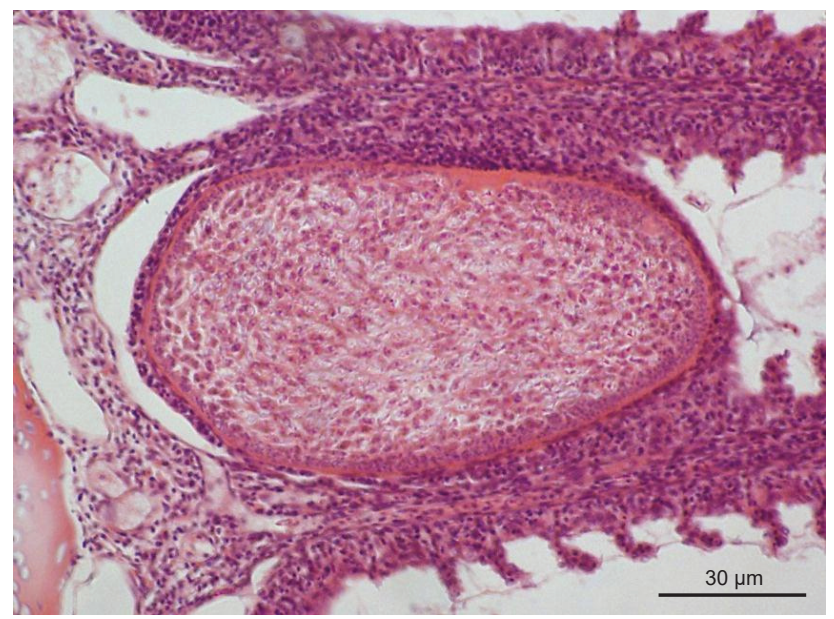

Fig. 2. Henneguya latesi Tripathi, 1953 in the gills of Lates calcarifer (Bloch) - photo by C. Székely.

the spores' placement is not as clear as with $H$. creplini (Fig. 1B).

Henneguya piaractus Martins et Souza, 1997 infects the gills of Piaractus mesopotamicus (Holmberg) (Characiformes: Serrasalmidae) in Brazil, forming rounded to elongate plasmodia within the capillaries of the secondary gill lamellae (Eiras et al. 1999). In some elongate plasmodia the spores are also non-randomly disposed, placed with the major axis parallel to the length of the plasmodium. Spores are densely packed, suggesting also a maximisation of filling the available space (Fig. 1C).

Henneguya corruscans Eiras, Takemoto et Pavanelli, 2009 infects the gills of Pseudoplatystoma corruscans Spix et Agassiz (Siluriformes: Pimelodidae) in Brazil in an interlamellar position (Eiras et al. 2009) forming round, oval, elongated or irregular plasmodia. In some of the oval plasmodia spores are also densely packed with the same disposition of $H$. piaractus, but the density of space filling is apparently more efficient. As shown in Fig. 1D, the package of spores seems more adapted to the shape of the internal space of the plasmodium.
Henneguya latesi Tripathi, 1953 infects the gills of Lates calcarifer (Bloch) (Perciformes: Latidae) in Malaysia. Plasmodia of this species were exclusively found in different parts of the gill filaments inside the multilayered epithelium between two lamellae. In some plasmodia the arrangement of spores shows an ordinate pattern, although not so evident as in the other cases (Fig. 2).

The finding of these features led to an extensive literature survey trying to find similar observations - all the papers used by Eiras (2002) and Eiras and Adriano (2012) for production of the synopsis of the species of Henneguya, including nearly all the species described to date, were examined. Ocasionally, other papers not dealing directly with species descriptions were also scrutinised.

This survey led to the observation of one more case of non-random distribution of spores of Henneguya curimata Azevedo et Matos, 2002, parasitising the kidney of Curimata inornata Vari (Characiformes: Curimatidae) in Brazil, showing spores disposed parallel to each other and densely packed (Azevedo and Matos 2002).

The facts referred to in previous paragraphs seem to be uncommon and occur only in a few species of Henneguya from some hosts. Some of these parasite species were reported from a number of different hosts not presenting the same features, the spores being randomly distributed within the plasmodia (Haaparanta et al. 1994, Martins and Souza 1997, Molnár 1998, Adriano et al. 2005, Campos et al. 2011). Furthermore, in the same host, an ordinate distribution of the spores was observed in some plasmodia, whereas were randomly placed in others (Eiras et al. 1999, 2009). Taking into account the above data, it is clear that this kind of spore arrangement is unusual and difficult to explain.

First of all, the patterns highlighted by the histological sections may depend upon the way the cut of the histological blocks is made, as the spores have no symmetric shape. In any of the figures reported herein the final result of the section could be very different if the cuts were made on a different orientation of the histological block, 
leading to a different observation of the position of spores. However, it is reasonable to suppose that thousands of histological cuts of a number of myxosporean plasmodia are made every year all over the world, concerning different myxosporean species, and such a spore arrangement was apparently reported very rarely.

This peculiar arrangement of spores strongly suggests that it leads to an efficient way of filling the plasmodium, i.e. a way of producing a great number of spores. If this is true, such a mechanism would have obvious important consequences as an adaptative factor increasing the probability of transmission to the next host in the life cycle. Moreover, it would explain why this feature is apparently observed only in spores with a tail-like appendage. A spore oval in shape (as species of Myxobolus Bütschli, 1882), would not 'need' a specific arrangement to fill completely the available space within the plasmodium.

This led us to verify mathematically, whether or not, this type of distribution corresponds to the most efficient way of filling the space. Several tests were made using the available images, aiming to measure the spore density whithin the plasmodia. The global image threshold using Otsu's method (Otsu 1979), as well as other parametrisations for the thresholds, were tried using Matlab programming language. Regarding the images observed, and concerning the geometry of the spores' disposition within plasmodia, there are some comments to be made. It is clear that from a mathematical point of view, the previous images did not allow us to conclude that the observed pattern corresponds to an optimisation of the available space in terms of the density of spores.

Since the number of images is low, we do not have enough information to infer about the spores 3D distribution on the space (plasmodium). The plan presented on each image just allows us to check the density on the 2D surface, and even then, the image definition is not good enough to detect spores placed along a normal (perpendicular) direction concerning the missing dimension. As so, in an optimisation point of view, if these images show any optimal (or near-optimal) solution, there are certainly other constrains that we are not taking into account, or the objective function (here considered as maximise the number of spores present within the plasmodium or, similarly, maximise the spores density within the container area) is not properly defined.

In spite of this conclusion, we believe that the peculiar arrangement of the spores provides a means of increasing the number of spores within a space unit. The amount of spores that are disposed side by side in a compact arrangement is clearly different from the number obtained when the spores are mixed with one another without any regularity, and we postulate it was not obtained by chance.

A number of questions arise from these observations: what kind of mechanism(s) is involved in these arrangements? Why is this feature apparently very rare and observed in a very limited species of Henneguya so far? Why is it observed, in one particular host, only in a small number of plasmodia? We think that intrinsic and extrinsic factors may be involveld in this peculiar arrangement of spores within the plasmodia.

In myxozoans, the patterns of sporogony differ between taxa, but the assembly of the spores requires cellular interactions, including motility, aggregation and the formation of cell-cell junctions (Okamura et al. 2015). Like in other cnidarians, myxozoans demonstrate motility at the cell (Sitjà-Bobadilla et al. 1995, Cho et al. 2004, Alama-Bermejo et al. 2012), and in some cases, at the whole organism level in both Malacosporea and Myxosporea (Feist et al. 2015). Some studies have pointed out motility in sporogonic stages (Grabner and El-Matbouli 2010, Alama-Bermejo et al. 2012), and recently a motile elongated plasmodium of Ceratomyxa vermiformis Adriano et Okamura, 2017 was video taped by Adriano and Okamura (2017), having coordinated locomotory undulating movement. Hartigan et al. (2016) described in detail the mechanism of the movements of blood stages of Sphaerospora molnari Lom, Dyková, Pavlásková et Grupcheva, 1983. So, we admit the influence of some kind of motility, at least of the sporogonic stages during the sporogony process, or even of spores. Concerning the movement of spores, there are only two papers where motility of mature spores was observed, as far as the authors are aware. That is the case of Fabespora vermicola Overstreet, 1976 infecting the digenean Crassicutis archosargi Spark and Thatcher, 1960 a parasite of the fish Archosargus probatocephalus Walbaum (see Overstreet 1976, Weidner and Overstreet 1979). Overstreet (1976) stated that "examining trematodes under minimal coverslip pressure, I saw paired spores moving through the tegument to the external medium". This interpretation may be questionable because the pressure of the coverslip, although minimal, could perhaps cause the movement of spores. However, the same author states in the same paper "In one instance, I observed under high magnification a single released spore actively moving at a relatively moderate speed. The spore appeared to undulate for periods of up to several minutes, followed by intermitent pauses before continuation of the locomotory behavior. Such behavior has not been reported previously for myxosporidans". His conclusion was reinforced later by Weidner and Overstreet (1979) stating that isolated spores of $F$. vermicola move by themselves once separated from the host.

An arrangement of spores as depicted in Fig. 1A,C is difficult to explain without the existence of some kind of motility, either related to the spores themselves, either to early sporogonic stages. The arrangements depicted in Fig. 1B,D and in Fig. 2 are probably easier to understand. During the sporogonic development spores begin to mature in the centre of the plasmodia. Therefore, it is reasonable to expect, due to the elongated form of the spores, that the formation of spores in the centre may cause some kind of gliding behavior and package effect of the spores as their formation goes on. During the formation of spores there are modifications in the cells which originate from different parts of the spores involving changes in shape and volume of the resulting spore. For these reasons, it is probable that gliding movements may occur and we admit that 
compact groups of spores are formed accompanying the general shape of the 'container', i.e. the plasmodium walls.

In all the tentative explanations referred to above we consider only intrinsic factors which develop inside the plasmodia. However, external factors may eventually be more important for the arrangement of spores. Their position inside the plasmodium likely depends on the effects of the surroundings, such as on the position of the plasmodia in the gills. In the case of lamellar plasmodia, the water pressed through the gills slit compress the shape of plasmodium and it is supposed to indirectly move spores inside the cysts and help their arrangement. In the case of filamental plasmodia the shape of the cyst is more affected by the shape of gill filaments. Those developing inside the gill arteries are compressed by the connective tissue and muscular elements of the arteries and a similar effect may occur also on plasmodia developing outside arteries.

If the plasmodium located in the fins, it is supposed that the movement of the fins creates pressure on the plasmodium leading to movement of the inside spores. The influence of external factors would explain why the non-random disposition of spores was observed in species developing in the gills or in the fins. The only case of such an arrangement in internal organs was the one depicted by Azevedo and Matos (2002) for H. curimata in the kidney of Curimata inornata. However, 'undulating' movements of the kidney during the host swimming may have the same effects as water movement around the gills plasmodia, or the movements of the fins, i.e. in this case the external factors would be also very important for the arrangement of the spores.

Therefore, and taken the different observations as a whole, it seems that the arrangement of the spores could be caused principally by external forces. It is highly probable that the final result of the spore arrangement is due to combination of factors, both internal and external, whose relative importance is unknown.

Acknowledgements. Participation of J.C. Eiras, A. Saraiva and C. Cruz on this research was partially supported by the European Regional Development Fund (ERDF) through the COMPETE - Operational Competitiveness Programme, and national funds through FCT - Foundation for Science and Technology (project PEst-C/MAR/LA0015/2013). E.A. Adriano was supported by a research productivity grant from CNPq (Proc. No. 305630/2013-0), while C. Székely and K. Molnár were supported by the GINOP 2.3.3-15-2016-00004 Project.

\section{REFERENCES}

Adriano E.A., Arana S., Cordeiro N.S. 2005: Histology, ultrastructure and prevalence of Henneguya piaractus (Myxosporea) infecting the gills of Piaractus mesopotamicus (Characidae) cultivated in Brazil. Dis. Aquat. Org. 64: 229-235.

Adriano E.A., OKamura B. 2017: Motility, morphology and phylogeny of the plasmodial worm, Ceratomyxa vermiformis $\mathrm{n} . \mathrm{sp}$. (Cnidaria: Myxozoa: Myxosporea). Parasitology 144: 158-168.

Alama-Bermejo G., Bron J.E., Raga J.A., Holzer A.S. 2012: 3D morphology, ultrastructure and development of Ceratomyxa puntazzi stages: first insights into the mechanisms of motility and budding in the Myxozoa. PLoS ONE 7: e32679.

Azevedo C., Matos E. 2002: Fine structure of the myxosporean, Henneguya curimata n. sp., parasite of the Amazonian fish, Curimata inornata (Teleostei, Curimatidae). J. Eukaryot. Microbiol. 49: 197-200.

Campos C.M., Moraes J.R.E., Moraes F.R. 2011: Histopatologia de brânquias de Piaractus mesopotamicus (Holmberg, 1887) e Prochilodus lineatus (Valenciennes, 1836) parasitados por monogêneos e mixosporídios, capturados no Rio Aquidauana, Mato Grosso do Sul, Brasil. Rev. Bras. Parasitol. Vet. 20: 67-70.

Cho J.B., Kwon S.R., Kim S.K., Nam Y.K., Kiм K.H. 2004: Ultrastructure and development of Ceratomyxa protopsettae Fujita, 1923 (Myxosporea) in the gallbladder of cultured olive flounder, Paralichthys olivaceus. Acta. Protozool. 43: 241-250.

Dykoví I., Lom J. 2007: Histopathology of Protistan and Myxozoan Infections in Fishes. An Atlas. Academia, Praha, 219 pp.

Eiras J.C. 2002: Synopsis of the species of the genus Henneguya Thélohan, 1892 (Myxozoa, Myxosporea, Myxobolidae). Syst. Parasitol. 52: 34-45.

Eiras J.C., Adriano E.A. 2012: Checklist of the species of the genus Henneguya Thélohan, 1892 (Myxozoa, Myxosporea, Myxobolidae) described between 2002 and 2012. Syst. Parasitol. 83: 95-104.

Eiras J.C., Pavanelli G.C., Ranzani Paiva M.J.T., TakemoTO R.M. 1999: Gill histopathology of Piaractus mesopotamicus (Osteichthyes: Serrasalmidae) infected by Henneguya piaractus Martins et Souza, 1997 (Myxozoa: Myxobolidae). Res. Rev. Parasitol. 59: 117-120.
Eiras J.C., Takemoto R.M., Pavanelli G.C. 2009: Henneguya corruscans n. sp. (Myxozoa, Myxosporea, Myxobolidae), a parasite of Pseudoplatystoma corruscans (Osteichthyes, Pimelodidae) from the Paraná River, Brazil: a morphological and morphometric study. Vet. Parasitol. 159: 154-158.

Feist S.W., Morris D.J., Alama-Bermejo G., Holzer A.S. 2015: Cellullar processes in myxozoans. In: B. Okamura, A. Grhul and J.L. Bartholomew (Eds.), Myxozoan Evolution. Ecology and Development. Springer International Publishing, Cham, pp. 139-154.

Grabner D.S., El-Matbouli M. 2010: Tetracapsuloides bryosalmonae (Myxozoa, Malacosporea) portal of entry into the fish host. Dis. Aquat. Org. 90: 197-206.

Haaparanta A., Valtonen E.T, Hoffmann R.W. 1994: Pathogenicity and seasonal occurrence of Henneguya creplini (Protozoa, Myxosporea) on the gills of perch Percafluviatilis in central Finland. Dis. Aquat. Org. 20: 15-24.

Hartigan A., Estensoro I, Vancová M., Bílý T., Patra S., Eszterbauer E., Holzer A.S. 2016: New cell motility model observed in parasitic cnidarian Sphaerospora molnari (Myxozoa: Myxosporea) blood stages in fish. Sci. Rep. 6: 39093.

Martins M.L., Souza V.N. 1997: Henneguya piaractus n. sp. (Myxozoa: Myxobolidae), a gill parasite of Piaractus mesopotamicus Holmberg, 1887 (Osteichthyes: Characidae), in Brazil. Rev. Brasil. Biol. 57: 239-245.

Molnár K. 1998: Taxonomic problems, seasonality and histopathology of Henneguya creplini (Myxosporea) infection of the pikeperch Stizostedion lucioperca in Lake Balaton. Folia Parasitol. 45: 261-269.

Moreira G.S.A., Adriano E.A., Silva M.R.M., Ceccarelli P., MaiA A.A.M. 2014: Morphology and 18S rDNA sequencing identifies Henneguya visibilis n. sp., a parasite of Leporinus obtusidens from Mogi Guaçú River, Brazil. Parasitol. Res. 113: 81-90.

Okamura B., Gruhl A., Bartholomew J.L. 2015: An Introduction to Myxozoan Evolution, Ecology and Development. In: B. Okamura, A. Grhul and J.L. Bartholomew (Eds.), Myxozoan Evolution. Ecology and Development. Springer International Publishing, Cham, pp. 1-20. 
OTsU N. 1979: A threshold selection method from Gray-Level histograms. IEEE Transact. Syst. Man Cybern. 9: 62-66.

Overstreet R.M. 1976: Fabespora vermicola sp. n., the first myxoporidan from a platyhelminth. J. Parasitol, 62: 680-684.

Sitjà-Bobadilla A., Palenzuela O., Alvarez-Pellitero P. 1995: Ceratomyxa sparusaurati n. sp. (Myxosporea: Bivalvu- lida), a new parasite from cultured gilthead seabream (Sparus aurata L.) (Teleostei: Sparidae): light and electron microscopic description. J. Euk. Microbiol. 42: 529-539.

Weidner E., Overstreet R.M. 1979: Sporogenesis of a myxosporidian with motile spores. Cell Tissue Res. 201: 331-342.

Cite this article as: Eiras J.C., Cruz M., Cruz C., Saraiva A., Adriano E.A., Székely C., Molnár K. 2017: Observations on non-randomly distribution of spores of Henneguya spp. (Cnidaria: Myxosporea: Myxobolidae) within plasmodia. Folia Parasitol. 64: 019. 